\title{
HYPERTHERMIA EFFECT ON HUMAN NORMAL BREAST (MCF-10A) AND CANCER (MDA-MB 231 AND MCF-7) CELLS
}

\begin{abstract}
ASITA ELENGOE ${ }^{1}$, NOOR JAHAN BANU MOHAMMED ALITHEEN ${ }^{2}$, SALEHHUDDIN HAMDAN ${ }^{3 *}$
${ }^{1}$ Department of Biotechnology, Faculty of Science, Lincoln University College, 47301 Petaling Jaya, Selangor, Malaysia, ${ }^{2}$ Department of Cell and Molecular Biology, Faculty of Biotechnology and Biomolecular Sciences, Universiti Putra Malaysia, Serdang, Selangor, Malaysia, ${ }^{3}$ Department of Biosciences and Health Sciences, Faculty of Science, Universiti Teknologi Malaysia, 81310 Skudai, Johor, Malaysia. Email: saleh65@utm.my
\end{abstract}

Received: 27 November 2018, Revised and Accepted: 14 January 2019

\section{ABSTRACT}

Objective: In this study, the hyperthermia effect on the viability of human normal breast (MCF-10A) and cancer (MDA-MB 231 and MCF-7) cells was evaluated by MTT assay.

Methods: Cells were exposed to heat at $38^{\circ} \mathrm{C}, 39^{\circ} \mathrm{C}, 40^{\circ} \mathrm{C}, 41^{\circ} \mathrm{C}, 42^{\circ} \mathrm{C}, 43^{\circ} \mathrm{C}$, and $44^{\circ} \mathrm{C}$ for five different durations of heat exposure $(0.5,1,2,3$, and $4 \mathrm{~h})$. Breakpoint temperatures of MCF-10A, MDA-MB 231, and MCF-7 were determined using cumulative equivalent $43^{\circ} \mathrm{C}\left(\mathrm{CEM}_{43}\right)$ model. This model was first time used to calculate thermal isoeffect dose (TID) for MCF-10A, MDA-MB 231, and MCF-7.

Results: MCF-10A started to die at $42^{\circ} \mathrm{C}$ for $3 \mathrm{~h}$ while MDA-MB 231 and MCF-7 need a temperature of $38^{\circ} \mathrm{C}$ for $0.5 \mathrm{~h}$; thus, they were identified as the threshold temperatures in $\mathrm{CEM}_{43}$ model. Furthermore, the effect of " $43^{\circ} \mathrm{C}$ incubator $2 \mathrm{~h}$ " had similar total thermal dose as " $44^{\circ} \mathrm{C}$ incubator $0.5 \mathrm{~h}$ " for MDA-MB 231 and MCF-7. In addition, " $43^{\circ} \mathrm{C}$ incubator $3 \mathrm{~h}$ " effect had also almost the same thermal dose as " $44^{\circ} \mathrm{C}$ incubator $1 \mathrm{~h}$ " for MDA-MB 231 and MCF-7.

Conclusion: A better understanding of the significant correlations between $\mathrm{CEM}_{43}$ and response parameters in clinical trials could be useful to treat breast cancer patients.

Keywords: Hyperthermia, MCF-10A, MDA-MB 231, MCF-7, cumulative equivalent $43^{\circ} \mathrm{C}$ model, Thermal isoeffect dose

(c) 2019 The Authors. Published by Innovare Academic Sciences Pvt Ltd. This is an open access article under the CC BY license (http://creativecommons. org/licenses/by/4. 0/) DOI: http://dx.doi.org/10.22159/ajpcr.2019.v12i3.30956

\section{INTRODUCTION}

Breast cancer is a major global health problem and the most common invasive cancer in women of all ethnic backgrounds. Worldwide, estimated 1.6 million new cases are diagnosed for each year $[1,2]$. There are many attempts with a multitude of novel therapeutic concepts although the conventional methods based on surgery, chemotherapy, radiotherapy, or their combinations steadily develop [3].

Hyperthermia among them has attracted significant attention and already entered clinical practice as an adjuvant to chemotherapy and radiotherapy [4]. It is used to raise the temperature of a region of the body affected by cancer with minimal or no damaging healthy tissues [5]. Thermal chemosensitization and thermal radiosensitization effects have been observed both in vivo and in in vitro cell culture experiments [6]. At least 18 randomized studies have demonstrated that the synergistic effects of combining hyperthermia with either chemotherapy or radiotherapy or both to achieve better therapeutic effects [5]. This was demonstrated for the breast, cervix, head and neck, pancreas, bladder, esophagus, prostate, lung, vulva/vagina cancers, and for melanoma. Hyperthermia has shown great potential in overcoming multidrug resistant (e.g. doxorubicin) which may result in the accumulation of chemotherapy agents within the target cells [6].

Rolf (2008) observed that synergism as a continuous change with increasing the rate temperatures at which cells are killed by the drug [7]. It is generally accepted that when temperatures are raised from $37^{\circ} \mathrm{C}$ to over $40^{\circ} \mathrm{C}$, most alkylating agents (e.g., cyclophosphamide and ifosfamide), platinum compounds, and nitrosoureas (bis-chloroethylnitrosourea, and 1-2-chloroethyl-3-cyclohexyl-1-nitrosourea) are linearly enhanced in their cytotoxic effect. On other the hand, threshold temperatures for the interaction with heat at or near $42.5^{\circ} \mathrm{C}$ have a synergistic effect with doxorubicin or bleomycin meanwhile most antimetabolites (e.g. 5 -fluorodeoxyuridine and methotrexate), vinca alkaloids, or taxanes show independent action $[7,8]$.

Thus, thermal isoeffect dose (TID) is important because it helps to predict the outcome in vitro for a given heat dose. It can be applied to sensitize phenomena with cytostatic drugs, anticancer agents, and radiation therapy to improve better outcome in breast cancer treatment. The TID for induction of cell death was found to be closely related to the amount of energy required to inactivate proteins and enzymes [9]. Although the Arrhenius analysis could be used to calculate the inactivation energy, it is hard to compare two different time-temperature combinations in that plot. Therefore, Sapareto and Dewey [10] described the term "TID" (meaning two different time-temperature combinations produced the same cell killing effect) for comparing different time-temperature combinations. Calculation of the thermal dose applied in hyperthermia has been successfully integrated into the concept of a TID during a certain duration exposure at a given temperature.

Treatment outcome varied greatly between different types of cell lines although the same or different settings of hyperthermia used. For example, the proliferation of human osteosarcoma cells was inhibited by hyperthermia treatment at $42^{\circ} \mathrm{C}$ whereas heat shock at $44^{\circ} \mathrm{C}$ inhibited proliferation significantly in normal fibroblasts cells [9]. Therefore, different mechanisms were involved in heat shock-induced cell death among normal cell and cancer cell [5]. According to Omar and Lanks [11] investigated that cancer cells are more susceptible to killing by heat than normal cells after the hyperthermia treatment $\left(43^{\circ} \mathrm{C}-45^{\circ} \mathrm{C}\right)$. 
In the present study, it was aimed to investigate the percentage viability evaluated by MTT assay with time of heat treatments in breast carcinoma (MDA-MB 231 and MCF-7) and normal breast (MCF-10A) cell lines using seven different temperatures $\left(38^{\circ} \mathrm{C}, 39^{\circ} \mathrm{C}, 40^{\circ} \mathrm{C}, 41^{\circ} \mathrm{C}\right.$, $42^{\circ} \mathrm{C}, 43^{\circ} \mathrm{C}$, and $44^{\circ} \mathrm{C}$ ) for five different durations of heat exposure $(0.5,1,2,3$, and $4 \mathrm{~h})$. Moreover, breakpoint temperatures of MCF-10A, MDA-MB 231, and MCF-7 cells were determined using cumulative equivalent $43^{\circ} \mathrm{C}\left(\mathrm{CEM}_{43}\right)$ model. This model was first time used to calculate TID for MCF-10A, MDA-MB 231, and MCF-7 cell lines.

\section{METHODS}

\section{Cells}

The human breast cancer lines (MDA-MB 231 and MCF-7) were cultured in Dulbecco's modified Eagle's medium (DMEM) supplemented with $4.5 \mathrm{~g} / \mathrm{L}$ glucose, $1.5 \mathrm{~g} / \mathrm{L}$ sodium bicarbonate, 100 $\mathrm{U} / \mathrm{mL}$ penicillin, $100 \mathrm{mg} / \mathrm{mL}$ streptomycin, and $10 \%$ fetal calf serum. DMEM/Ham's Nutrient Mixture F-12 was supplemented with $1 \%$ penicillin/streptomycin, $5 \%$ horse serum $1 \mathrm{ng} / \mathrm{mL}$ of cholera toxin, $10 \mu \mathrm{g} / \mathrm{ml}$ of human insulin, $10 \mathrm{ng} / \mathrm{ml}$ of epidermal growth factor, and $0.5 \mu \mathrm{g} / \mathrm{ml}$ of hydrocortisone which was used to culture MCF-10A cells. Cells were maintained in a $5 \% \mathrm{CO}_{2}$ humidified incubator at $37^{\circ} \mathrm{C}$

\section{Hyperthermic exposure}

MCF-10A, MDA-MB 231, and MCF-7 cells, $1 \times 10^{4}$ cells/well in $200 \mu$ culture medium, were seeded in each well of 96 -well plates and precultured overnight incubation at $37^{\circ} \mathrm{C}$. Then, hyperthermic exposure was performed by placing culture plates in an incubator maintained at $38^{\circ} \mathrm{C}, 39^{\circ} \mathrm{C}, 40^{\circ} \mathrm{C}, 41^{\circ} \mathrm{C}, 42^{\circ} \mathrm{C}, 43^{\circ} \mathrm{C}$, and $44^{\circ} \mathrm{C}$ for studying cytotoxicity of cells. Well temperature was monitored and maintained within $0.1^{\circ} \mathrm{C}$ during the treatment period. Cultured cells were maintained at $37^{\circ} \mathrm{C}$ served as controls for all experiments. Cultured cells were subjected to $0.5,1,2,3$, or $4 \mathrm{~h}$ of hyperthermic exposure for each temperature.

\section{Observation under phase contrast microscope}

After hyperthermia treatment, MCF-10A, MDA-MB 231, and MCF-7 cells were observed using a phase contrast microscope (Nikon Ti Eclipse). The photographs were taken at $\times 10 / 0.03$ magnification.

\section{MTT assay}

MTT assay $[12,13]$ is a colorimetric assay for measuring the activity of cellular enzymes that reduce the tetrazolium dye, MTT, to its insoluble formazan, giving a purple color. The culture medium was removed from the culture plates after appropriate treatment and added with $200 \mu \mathrm{l}$ of fresh culture medium and $20 \mu \mathrm{l}$ of MTT media. The well plates were incubated for $4 \mathrm{~h}$ at $37^{\circ} \mathrm{C}$. The mixture was aspirated slowly from the wells. Then, a volume of $200 \mu \mathrm{l}$ of isopropanol was added to each well. Well plates were kept in dark for 15 minutes. Finally, absorbance at $570 \mathrm{~nm}$ in each well was measured using an ELISA microplate reader (BioTek Instrument). This value was then background subtracted (from media only wells) at $650 \mathrm{~nm}$ and compared with controls, which are the values of cells without any treatment for obtaining cell growth. The average absorbance of the control cells exposed to free culture medium was set to represent $100 \%$ of viability, and the results were expressed as percentage of these controls.

Cell viability percentage was calculated using the following equation as below:

$\%$ cell viability $=($ Optical density of hyperthermia treated cells $/ 0$ ptical density of untreated cells) $\times 100 \%$.

\section{Statistical analysis}

Results were expressed as a mean \pm standard error of the mean (SEM) (SEM was within $5 \%$ of the average). The mean values were calculated from data taken from one experiment performed in triplicates. Significance testing was performed where indicated using one-factor analysis of variance. The differences were evaluated statistically significant at $\mathrm{p}<0.05$.

\section{Calculation of thermal isoeffect dose}

The concept of a TID has been successfully integrated from the calculation of the thermal dose during a certain duration of heat exposure at a given temperature. This relationship can be expressed mathematically by the following isoeffect equation:

$$
\mathrm{t}_{1}=\mathrm{t}_{2} * \mathrm{R}\left(\mathrm{T}_{2}-\mathrm{T}_{1}\right)
$$

where $\mathrm{T}_{1}$ and $\mathrm{T}_{2}$ are two different temperatures of treatment and $\mathrm{t}_{1}$ and $t_{2}$ are the duration exposure of heat at temperature $T_{1} \& T_{2}$, respectively. The shape of the dose-response curve is defined by empirical value, R. $R$ is usually assumed as 0.5 above $43{ }^{\circ} \mathrm{C}$ and 0.25 below $43^{\circ} \mathrm{C}$ by Sapareto and Dewey [10]. Heating time periods at different temperatures are converted into equivalent heating minutes at $43^{\circ} \mathrm{C}$ which can be explained using the TID concept. From equation (1), if set $\mathrm{T} 1=43^{\circ} \mathrm{C}$ and allow $\mathrm{T}_{2}$ to be varied during heat treatment, get which is the widely used cumulative equivalent minutes $43^{\circ} \mathrm{C}$ model.

$$
\mathrm{CEM}_{43}=\int \mathrm{R}(43-\mathrm{T}[\mathrm{t}]) \mathrm{dt}
$$

\section{RESULTS AND DISCUSSION}

Heat shock treatment on the viability of MCF-10A, MDA-MB 231 and MCF-7 cell lines

In the present study, hyperthermia-induced cytotoxicity was assessed using MTT assay which confirmed that hyperthermia stress greatly decreased cell viability of MDA-MB 231 and MCF-7 cells with increasing temperature (from $37^{\circ} \mathrm{C}$ to $44^{\circ} \mathrm{C}$ ) and duration of heat exposure (from 1 to $4 \mathrm{~h}$ ) while MCF-10A cells were maintained the same number as before hyperthermia treatment (as control) from $37^{\circ} \mathrm{C}$ to $42^{\circ} \mathrm{C}$ for $2 \mathrm{~h}$. There was a significant statistical difference when the percentage viability of MCF-10A, MDA-MB 231, and MCF-7 cells after the treatment was compared with the control $(100 \%)(p<0.05)$ (Table 1). However, there was a mild decrease in the sum of MCF-10A viable cells as the duration of heat exposure increased from 2 to $3 \mathrm{~h}$ at the temperature of $42^{\circ} \mathrm{C}$. Based on Table 1, MCF-10A cell viability did not cause any decrease compared to control $(100 \%)$ from $37^{\circ} \mathrm{C}$ to $40^{\circ} \mathrm{C}$ for 0.5 to $4 \mathrm{~h}$ and $42^{\circ} \mathrm{C}$ for 0.5 to $2 \mathrm{~h}$.

Treatment outcome varied hugely between different types of cell lines although the same settings of hyperthermia used. Furthermore, small changes in hyperthermia settings could influence greatly difference in the final treatment outcome. Therefore, the viability of normal and cancer cells is highly influenced by the temperature and duration exposure of heat (hyperthermia settings). For example, induction of apoptosis for human fibrous histiocytoma cells was inhibited hyperthermia treatment at $43^{\circ} \mathrm{C}$ for $1 \mathrm{~h}$, a temperature lower than that was not able to induce apoptosis although increase the duration of heat exposure. However, Yonezawa et al. observed that necrotic death occurred at temperature of $46^{\circ} \mathrm{C}$ for $1 \mathrm{~h}$ where cell death was passive and involved lysis formation from the damaged cell and the release of its cellular content to the surrounding environment [14]. In contrast, heat shock at $44^{\circ} \mathrm{C}$ inhibited induction of apoptosis significantly in normal fibroblasts cells [9]. Therefore, different mechanisms were involved in heat shock-induced cell death among normal cell and cancer cells [5].

In this study, MDA-MB 231 and MCF-7 cells were started to die at temperature of $38^{\circ} \mathrm{C}$ for $0.5 \mathrm{~h}$, whereas MCF-10A cell line was started to show cytotoxicity at $42^{\circ} \mathrm{C}$ for $3 \mathrm{~h}$ of hyperthermic exposure. It was reasonable because MDA-MB 231 and MCF-7 cell lines sensitive to heat; therefore, the facilitating effect of hyperthermia to cancer cell was obvious. This was due to MDA-MB 231 and MCF-7 cells did not have a defense system against heat, as did MCF-10A cells [15]. MCF-10A might express heat shock-induced proteins to reactivate denatured proteins; degrade abnormally structured proteins; and inhibit secretion of abnormal proteins and assisting the transfer of secretory proteins by blockage of folding [16]. In addition, Hsp70 induction by hyperthermia treatment in cancer cells is lower than those in normal cells [17]. 
Table 1: Cell viability percentage of MCF-10A, MDA-MB 231, and MCF-7 following heat treatment ${ }^{\mathrm{a}}$

\begin{tabular}{|c|c|c|c|c|c|c|c|c|}
\hline Cells & Time (hours) & $38^{\circ} \mathrm{C}$ & $39^{\circ} \mathrm{C}$ & $40^{\circ} \mathrm{C}$ & $41^{\circ} \mathrm{C}$ & $42^{\circ} \mathrm{C}$ & $43^{\circ} \mathrm{C}$ & $44^{\circ} \mathrm{C}$ \\
\hline \multirow[t]{6}{*}{ MCF-10A } & 0 & $100 \pm 0.086^{b}$ & $99.916 \pm 0.251^{b}$ & $99.815 \pm 0.185^{b}$ & $100 \pm 0.172^{\mathrm{b}}$ & $100 \pm 0^{\mathrm{b}}$ & $100 \pm 0.504^{\mathrm{b}}$ & $100 \pm 0.095^{\mathrm{b}}$ \\
\hline & 0.5 & $99.914 \pm 0.086$ & $99.916 \pm 0.168$ & $99.908 \pm 0.277$ & $99.914 \pm 0.172$ & $100 \pm 0 *$ & $99.496 \pm 0.504$ & $97.533 \pm 0.19$ \\
\hline & 1 & $99.829 \pm 0.342^{*}$ & $99.916 \pm 0.168$ & $100 \pm 0.185^{*}$ & $99.828 \pm 0.172 *$ & $100 \pm 0.19$ & $98.69 \pm 0.604$ & $93.074 \pm 0.38$ \\
\hline & 2 & $99.914 \pm 0.171$ & $99.916 \pm 0.251$ & $99.908 \pm 0.185^{*}$ & $99.914 \pm 0.172$ & $100 \pm 0^{*}$ & $96.979 \pm 0.705$ & $89.943 \pm 0.095^{*}$ \\
\hline & 3 & $100 \pm 0.086$ & $99.916 \pm 0.168$ & $99.908 \pm 0.185$ & $99.914 \pm 0.086$ & $100 \pm 0.095$ & $95.77 \pm 0.302$ & $87.192 \pm 0.285^{*}$ \\
\hline & 4 & $99.914 \pm 0.086$ & $99.916 \pm 0.168$ & $100 \pm 0.092$ & $99.914 \pm 0.258$ & $100 \pm 0 *$ & $91.339 \pm 0.403$ & $81.12 \pm 0.19 *$ \\
\hline \multirow[t]{5}{*}{ MDA-MB 231} & 0 & $100 \pm 1.221^{\mathrm{b}}$ & $100 \pm 0.592^{b}$ & $100 \pm 0.548^{b}$ & $100 \pm 1.261^{\mathrm{b}}$ & $100 \pm 1.469^{b}$ & $100 \pm 0.412^{\mathrm{b}}$ & $100 \pm 0.105^{b}$ \\
\hline & 1 & $94.229 \pm 1.221$ & $92.470 \pm 0.761^{*}$ & $90.351 \pm 1.206^{*}$ & $87.605 \pm 1.261^{*}$ & $83.736 \pm 1.889 *$ & $62.822 \pm 0.412 *$ & $47.950 \pm 0.210 *$ \\
\hline & 2 & $92.231 \pm 2.109^{*}$ & $89.932 \pm 0.761^{*}$ & $85.417 \pm 2.083^{*}$ & $79.892 \pm 3.466^{*}$ & $76.390 \pm 1.889 *$ & $52.317 \pm 1.339 *$ & $35.331 \pm 0.315^{*}$ \\
\hline & 3 & $84.795 \pm 1.554^{*}$ & $79.019 \pm 1.523^{*}$ & $67.325 \pm 4.605^{*}$ & $55.042 \pm 1.786 *$ & $46.065 \pm 3.148^{*}$ & $27.909 \pm 0.515^{*}$ & $10.410 \pm 0.210 *$ \\
\hline & 4 & $69.256 \pm 2.331^{*}$ & $55.076 \pm 0.592^{*}$ & $43.860 \pm 4.057^{*}$ & $29.412 \pm 3.027^{*}$ & $16.159 \pm 2.833^{*}$ & $9.784 \pm 0.515^{*}$ & $0.421 \pm 0.315^{*}$ \\
\hline \multirow[t]{5}{*}{ MCF-7 } & 0 & $100 \pm 1.378^{b}$ & $100 \pm 0.347^{b}$ & $100 \pm 2.286^{\mathrm{b}}$ & $100 \pm 1.038^{\mathrm{b}}$ & $100 \pm 3.769^{b}$ & $100 \pm 0.418^{\mathrm{b}}$ & $100 \pm 0.815^{b}$ \\
\hline & 0.5 & $98.163 \pm 0.459$ & $96.412 \pm 0.347$ & $94.857 \pm 1.029$ & $95.386 \pm 0.692$ & $92.108 \pm 1.413$ & $79.937 \pm 0.418$ & $68.685 \pm 0.931$ \\
\hline & 1 & $96.326 \pm 0.689^{*}$ & $94.290 \pm 0.694^{*}$ & $91.886 \pm 2.286^{*}$ & $89.043 \pm 2.653$ & $86.219 \pm 3.534^{*}$ & $64.159 \pm 0.627 *$ & $49.942 \pm 3.492 *$ \\
\hline & 2 & $93.226 \pm 1.378^{*}$ & $90.509 \pm 1.505^{*}$ & $86.629 \pm 2.857^{*}$ & $82.122 \pm 2.191 *$ & $80.448 \pm 1.885^{*}$ & $53.083 \pm 1.149 *$ & $43.772 \pm 2.678 *$ \\
\hline & 4 & $71.642 \pm 3.674^{*}$ & $57.639 \pm 2.894^{*}$ & $44.686 \pm 2.626^{*}$ & $31.949 \pm 2.884^{*}$ & $19.317 \pm 3.887^{*}$ & $11.494 \pm 0.418^{*}$ & $1.513 \pm 1.048^{*}$ \\
\hline
\end{tabular}

${ }^{a}$ Values represent mean \pm SD of three measurements from one independent experiment, ${ }^{b}$ The viability of MCF-10A, MDA-MB 231 and MCF-7 cells at $37^{\circ} \mathrm{C}$ as control,

${ }^{*} \mathrm{p}<0.05$. SD: Standard deviation

Therefore, MCF-10A cells were survived in undesirable circumstances such as at $42^{\circ} \mathrm{C}$ incubator hyperthermia for $2 \mathrm{~h}$. However, cell death of MCF-10A cells occurred when temperature increased to $42^{\circ} \mathrm{C}(>2 \mathrm{~h}$ of heat exposure). MCF-10A, MDA-MB 231, and MCF-7 cells might die exponentially by induction of apoptosis where cell death was active. When the temperature and duration exposure continued to increase, the cellular proteins denature at that high temperature and the cell dies passively (necrosis) before initiation of apoptosis for an extreme condition such as hyperthermia treatment on MDA-MB 231 and MCF-7 cells at a temperature of $44^{\circ} \mathrm{C}$ for $4 \mathrm{~h}$. In this study, normal cell line might die exponentially by induction of apoptosis but they might not reach until necrosis. Based on Gabai and Kabakov study [18], cytoskeleton damages and impairment of DNA repair system caused by hyperthermia treatment most likely occur during mitosis; therefore, MDA-MB 231 and MCF-7 (cancer) cells were more susceptible to heat than MCF-10A (normal) cell as cancer cells underwent faster cell division than normal cells. According to Watanabe and Suzuki (1989) [19], normal cells have reduced heat sensitivities 5-6 times at growing condition while cancer did not.

Although cancer therapies such as chemotherapy and radiotherapy can induce tumor cell apoptosis, physiological stress conditions such as growth factor, starvation, hypoxia, or heat can also be equally effective to DNA damaging treatment [20]. Abnormalities of these environmental factors affect tumor cell proliferation and response to antitumor therapy. Tumor cells with a disorganized and compact vascular structure have difficulty dissipating heat. Thus, hyperthermia might cause cancer cells to undergo apoptosis in direct response to heat. In contrast, healthy cells can more easily maintain at a normal temperature. Based on Urano et al. 1983 study [21], tumor cells might be more sensitive to lower temperature than normal tissue. Results from this study proved that Urano's hypothesis was right where MDA-MB 231 and MCF-7 cells were sensitive to the temperature of $38^{\circ} \mathrm{C}$. Besides that, as shown in Song et al.'s study [22], rat muscle and skin have a greatly enhanced blood flow at temperatures above $42^{\circ} \mathrm{C}$ while tumors have a greatly reduced blood flow at these temperatures. Reduction of blood flow and blood vessel density, resulting in regions with hypoxia and low $\mathrm{pH}$ levels, which is not found in normal tissues under undisturbed conditions. Hypoxia might exhibit anaerobic metabolism with resultant accumulation of lactic acid [23]. Acute acidification $\mathrm{pH}$ increases the rate of cell death by decrease heat shock protein levels [24].

\section{CONCLUSION}

The temperature of $42^{\circ} \mathrm{C}$ for $2 \mathrm{~h}$ was chosen as the most suitable temperature and duration of heat exposure to kill cancer cells (MDAMB 231 and MCF-7) without damaging normal cells (MCF-10A).

\section{Calculation of thermal isoeffect dose}

Cell death of MCF-10A, MDA-MB 231, and MCF-7 cell lines from $37^{\circ} \mathrm{C}$ to $44^{\circ} \mathrm{C}$ for $0.5 \mathrm{~h}$ up to $4 \mathrm{~h}$ was studied. When exponentially growing cultured cells (MCF-10A, MDA-MB 231, and MCF-7) were exposed to a defined temperature between $37^{\circ} \mathrm{C}$ and $44^{\circ} \mathrm{C}$ of heat exposure, a doseeffect curve was defined by plotting the rate of cell viability against the duration of hyperthermia. The survival curves of MDA-MB 231 and MCF-7 cell lines show a linear growth arrest at the beginning of heat exposure which reflecting reversible and nonlethal heat damage and then, followed by exponential cell death. This is typical "shoulder" which reflects a two-step process of cell killing. However, after increasing the temperature to $43^{\circ} \mathrm{C}$, more cells were killed during the same period of heat exposure. Therefore, it was concluded that once the hyperthermia treatment starts to show cytotoxicity, the rate of cell death, which is exponential with exposure duration, is dependent on the temperature of exposure [25].

Arrhenius plot is hard to use for compare two different timetemperature combinations. Thus, the term "TID” (meaning two different time-temperature combinations produced the same cell killing effect) was proposed by Sapareto and Dewey for comparing different timetemperature combinations [10]. The thermal dose can be described as the cumulative equivalent minutes at $43^{\circ} \mathrm{C}$ for any hyperthermia treatment

In this study, MDA-MB 231 and MCF-7 cells need temperature of $38^{\circ} \mathrm{C}$ for $0.5 \mathrm{~h}$ to induce apoptosis; therefore, it was identified as the threshold temperature in $\mathrm{CEM}_{43}$ model. For MCF-10A cell line, it was clearly indicated that a $42^{\circ} \mathrm{C}$ hyperthermia treatment for $3 \mathrm{~h}$ started to show very little cytotoxicity (Table 1), so the breakpoint for MCF-10A was at temperature of $42^{\circ} \mathrm{C}$ for $3 \mathrm{~h}$.

Table 2 shows calculated $\mathrm{CEM}_{43}$ for several different types of hyperthermia treatment based on the survival curves and Equation 2. As a result, the thermal dose (killing effect) of MCF-10A was lower than MDA-MB 231 and MCF-7 although same settings of hyperthermia used. Effect of " $43^{\circ} \mathrm{C}$ incubator $2 \mathrm{~h}$ " had similar total thermal dose as " $44^{\circ} \mathrm{C}$ incubator $0.5 \mathrm{~h}$ " for MDA-MB 231 and MCF-7 cells. In addition, " $43^{\circ} \mathrm{C}$ incubator $3 \mathrm{~h}$ " effect had also almost the same thermal dose as " $44^{\circ} \mathrm{C}$ incubator $1 \mathrm{~h}$ ” for MDA-MB 231 and MCF- 7 cell lines. This was defined as TID.

The thermal energy dose was required to induce exponential cell death (inactivation energy) which is closely correlated to that required for cellular proteins and enzymes denaturation [10]. It can be combined with cytostatic drugs (e.g. 5-fluorouracil, melphalan, and paclitaxel), 
Table 2: Equivalent heating minutes at $43^{\circ} \mathrm{C}$ using thermal isoeffective dose concept

\begin{tabular}{|c|c|c|}
\hline Cell & Treatment & $\mathrm{CEM}_{43}(\mathrm{~min})$ \\
\hline \multirow[t]{5}{*}{ MCF-10A } & $43^{\circ} \mathrm{C}$ incubator $0.5 \mathrm{~h}$ & 0.065 \\
\hline & $43^{\circ} \mathrm{C}$ incubator $1 \mathrm{~h}$ & 0.331 \\
\hline & $43^{\circ} \mathrm{C}$ incubator $2 \mathrm{~h}$ & 1.675 \\
\hline & $43^{\circ} \mathrm{C}$ incubator $3 \mathrm{~h}$ & 8.486 \\
\hline & $43^{\circ} \mathrm{C}$ incubator $4 \mathrm{~h}$ & 19.102 \\
\hline \multirow[t]{5}{*}{ MCF-10A } & $44^{\circ} \mathrm{C}$ incubator $0.5 \mathrm{~h}$ & 0.659 \\
\hline & $44^{\circ} \mathrm{C}$ incubator $1 \mathrm{~h}$ & 2.680 \\
\hline & $44^{\circ} \mathrm{C}$ incubator $2 \mathrm{~h}$ & 10.216 \\
\hline & $44^{\circ} \mathrm{C}$ incubator $3 \mathrm{~h}$ & 34.622 \\
\hline & $44^{\circ} \mathrm{C}$ incubator $4 \mathrm{~h}$ & 69.030 \\
\hline \multirow[t]{5}{*}{ MDA-MB 231} & $43^{\circ} \mathrm{C}$ incubator $0.5 \mathrm{~h}$ & 52.431 \\
\hline & $43^{\circ} \mathrm{C}$ incubator $1 \mathrm{~h}$ & 63.931 \\
\hline & $43^{\circ} \mathrm{C}$ incubator $2 \mathrm{~h}$ & 95.051 \\
\hline & $43^{\circ} \mathrm{C}$ incubator $3 \mathrm{~h}$ & 141.318 \\
\hline & $43^{\circ} \mathrm{C}$ incubator $4 \mathrm{~h}$ & 210.107 \\
\hline \multirow[t]{5}{*}{ MDA-MB 231} & $44^{\circ} \mathrm{C}$ incubator $0.5 \mathrm{~h}$ & 93.009 \\
\hline & $44^{\circ} \mathrm{C}$ incubator $1 \mathrm{~h}$ & 196.604 \\
\hline & $44^{\circ} \mathrm{C}$ incubator $2 \mathrm{~h}$ & 329.430 \\
\hline & $44^{\circ} \mathrm{C}$ incubator $3 \mathrm{~h}$ & 490.662 \\
\hline & $44^{\circ} \mathrm{C}$ incubator $4 \mathrm{~h}$ & 685.129 \\
\hline \multirow[t]{5}{*}{ MCF-7 } & $43^{\circ} \mathrm{C}$ incubator $0.5 \mathrm{~h}$ & 54.478 \\
\hline & $43^{\circ} \mathrm{C}$ incubator $1 \mathrm{~h}$ & 69.021 \\
\hline & $43^{\circ} \mathrm{C}$ incubator $2 \mathrm{~h}$ & 110.788 \\
\hline & $43^{\circ} \mathrm{C}$ incubator $3 \mathrm{~h}$ & 177.830 \\
\hline & $43^{\circ} \mathrm{C}$ incubator $4 \mathrm{~h}$ & 285.441 \\
\hline \multirow[t]{5}{*}{ MCF-7 } & $44^{\circ} \mathrm{C}$ incubator $0.5 \mathrm{~h}$ & 96.340 \\
\hline & $44^{\circ} \mathrm{C}$ incubator $1 \mathrm{~h}$ & 211.158 \\
\hline & $44^{\circ} \mathrm{C}$ incubator $2 \mathrm{~h}$ & 380.008 \\
\hline & $44^{\circ} \mathrm{C}$ incubator $3 \mathrm{~h}$ & 607.891 \\
\hline & $44^{\circ} \mathrm{C}$ incubator $4 \mathrm{~h}$ & 911.654 \\
\hline
\end{tabular}

Calculated $\mathrm{CEM}_{43}$ for different types of hyperthermia treatment for MCF-10A MDA-MB 231, and MCF-7 cell lines

anticancer agents, radiation, gene, and immunotherapy to achieve better outcome in breast cancer treatment. For example, the use of simultaneous application of weekly cisplatin and regional hyperthermia resulted in a $50 \%$ response rate. However, the response rate was about $15 \%$ without regional hyperthermia for patients with locoregional advanced cervix carcinoma in a clinical trial. A better understanding of the significant correlations between $\mathrm{CEM}_{43}$ and response parameters in clinical trials could useful to treat breast cancer patients.

\section{AUTHOR'S CONTRIBUTIONS}

AE designed the research, performed the experiments, analyzed data, and wrote the paper. NJBMA provided the MCF-10A cells. SH contributed critical comments and suggestions. All authors read and approved the final manuscript.

\section{CONFLICTS OF INTERESTS}

All authors of this publication declare that there are no conflicts of interest in publishing this research article.

\section{REFERENCES}

1. American Cancer Society. Cancer Facts and Figures. Atlanta, Georgia: American Cancer Society; 2014

2. Rukminingsih F, Andayani TM, Rahmawati F, Widayati K. Healthrelated quality of life in early breast cancer patients with hormone responsive. Int J Pharm Pharm Sci 2018;10:47-9.

3. Al Rashid MD, Bharawaj PV, Majumder S, Mandal V, Pal M, Mandal SC, et al. Antioxidant and anticancer activty of extract and fractions obtained from Diospyros melanoxylon roxb. leaves and correlation with their polyphenolic profiles. Int J Pharm Pharm Sci 2018;10:7-16

4. Chalkidou A, Simeonidis K, Angelakeris M, Samaras T, MartinezBoubeta C, Balcells, L. In vitro application of $\mathrm{Fe} / \mathrm{MgO}$ nanoparticles as magnetically mediated hyperthermia agents for cancer treatment. J Magn Magn Mater 2011;323:775-80.

5. van der Zee J. Heating the patient: A promising approach? Ann Oncol 2002;13:1173-84.

6. Hildebrandt B, Wust P, Ahlers O, Dieing A, Sreenivasa G, Kerner T, et al. The cellular and molecular basis of hyperthermia. Crit Rev Oncol Hematol 2002;43:33-56.

7. Issels RD. Hyperthermia adds to chemotherapy. Eur J Cancer 2008;44:2546-54.

8. Urano M, Kuroda M, Nishimura Y. For the clinical application of thermochemotherapy given at mild temperatures. Int J Hyperthermia 1999; 15:79-107.

9. Morris CC, Myers R, Field SB. The response of the rat tail to hyperthermia. Br J Radiol 1977;50:576-80.

10. Sapareto SA, Dewey WC. Thermal dose determination in cancer therapy. Int J Radiat Oncol Biol Phys 1984;10:787-800.

11. Omar RA, Lanks KW. Heat shock protein synthesis and cell survival in clones of normal and simian virus 40-transformed mouse embryo cells. Cancer Res 1984;44:3976-82.

12. Alley MC, Scudiero DA, Monks A, Hursey ML, Czerwinski MJ, Fine DL, et al. Feasibility of drug screening with panels of human tumor cell lines using a microculture tetrazolium assay. Cancer Res 1988;48:589-601.

13. Muruganandam L, Maheswari R. Anti-cancer studies of selective mannich bases by in silico method. Int J Curr Pharm Res 2018;10:81-5.

14. Yonezawa M, Otsuka T, Matsui N, Tsuji H, Kato KH, Moriyama A, et al. Hyperthermia induces apoptosis in malignant fibrous histiocytoma cells in vitro. Int J Cancer 1996;66:347-51.

15. Fukao H, Ikeda M, Ichikawa $\mathrm{T}$, Inufusa $\mathrm{H}$, Okada $\mathrm{K}$, Ueshima $\mathrm{S}$, et al. Effect of hyperthermia on the viability and the fibrinolytic potential of human cancer cell lines. Clin Chim Acta 2000;296:17-33.

16. Ellis RJ, van der Vies SM. Molecular chaperones. Annu Rev Biochem 1991;60:321-47.

17. Williams RS, Thomas JA, Fina M, German Z, Benjamin IJ. Human heat shock protein 70 (hsp70) protects murine cells from injury during metabolic stress. J Clin Invest 1993;92:503-8

18. Gabai VL, Kabakov AE. Tumor cell resistance to energy deprivation and hyperthermia can be determined by the actin skeleton stability. Cancer Lett 1993;70:25-31.

19. Watanabe M, Suzuki K. Heat sensitivity of human cancer cells and abnormal expression of heat shock protein 70. Gan No Rinsho 1989;35:1512-6.

20. Takasu T, Lyons JC, Park HJ, Song CW. Apoptosis and perturbation of cell cycle progression in an acidic environment after hyperthermia. Cancer Res 1998;58:2504-8.

21. Urano M, Rice L, Epstein R, Suit HD, Chu AM. Effect of whole-body hyperthermia on cell survival, metastasis frequency, and host immunity in moderately and weakly immunogenic murine tumors. Cancer Res 1983;43:1039-43.

22. Song CW, Lokshina A, Rhee JG. Implication of blood flow in hyperthermic treatment of tumors. IEEE Trans BME 1984;31:9-16.

23. Marder J, Eylath U, Moskovitz E, Sharir R. The effect of heat exposure on blood chemistry of the hyperthermic rabbit. Comp Biochem Physiol A Comp Physiol 1990;97:245-7.

24. Han JS, Storck CW, Wachsberger PR. Acute extracellular acidification increases nuclear associated protein levels in human melanoma cells during $42^{\circ} \mathrm{C}$ hyperthermia and enhances cell killing. Int J Hyperthermia 2002; 18: 404-15.

25. Dewhirst MW, Viglianti BL, Lora-Michiels M, Hanson M, Hoopes PJ. Basic thermal dosimetry and thermal thresholds for tissue damage from hyperthermia. Int J Hyperthermia 2003;19:267-94. 